\title{
SAINS TANAH - Journal of Soil Science and Agroclimatology
}

\section{Rubber bark dust-zeolite composite improves mechanical strength and microstructural characteristics of soft paddy soil}

\author{
Muhammad Rendana ${ }^{1 *}$, Wan Mohd Razi Idris ${ }^{2}$, Sahibin Abdul Rahim ${ }^{3}$, Zulfahmi Ali Rahman², Tukimat Lihan ${ }^{2}$ \\ ${ }^{1}$ Department of Chemical Engineering, Faculty of Engineering, Universitas Sriwijaya, Indonesia \\ ${ }^{2}$ Department of Earth Science and Environmental, Faculty of Science and Technology, Universiti Kebangsaan Malaysia, Malaysia \\ ${ }^{3}$ Environmental Science Program, Faculty of Science and Natural Resources, University of Malaysia Sabah, Malaysia
}

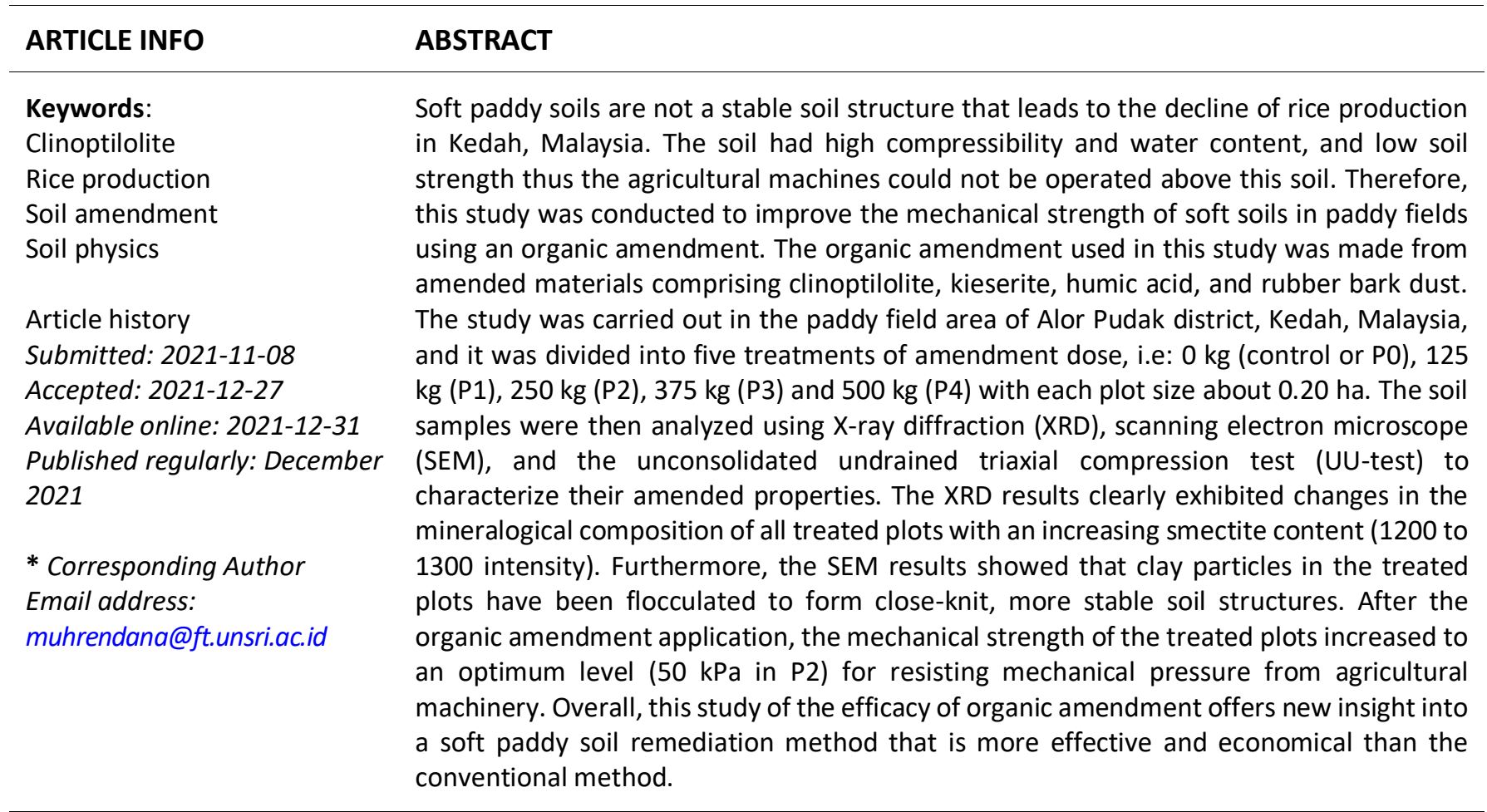

\begin{abstract}
How to Cite: Rendana, M., Idris, W.M.R., Rahim, S.H., Rahman, Z.A., Lihan, T. (2021). Rubber bark dust-zeolite composite improves mechanical strength and microstructural characteristics of soft paddy soil. Sains Tanah Journal of Soil Science and Agroclimatology, 18(2): 194-202. https://dx.doi.org/10.20961/stjssa.v18i2.56345
\end{abstract}

\section{INTRODUCTION}

Currently, soft paddy soil has become a great threat faced by farmers in Malaysia (Taufik et al., 2015). Soft soil is characterized by low mechanical strength and compressibility ( $<0.3 \mathrm{MPa}$ ) to withstand agricultural machines (Ahmad et al., 2020; Fauzi et al., 2018). According to previous data, in 2013, a total of 8,000 hectares of soft paddy soil areas has been found in the MADA area of Kedah, 5,200 hectares in the IADA area of Selangor, and 4,800 hectares in the KETARA area of Terengganu (Ahmad et al., 2021). In addition, soft soils are commonly known as soft clays and are stiff in their dry state but become soft when saturated with water. In general, the primary cause of soft soils is waterlogged soil conditions. Currently, paddy soils are being intensively used for rice production thus, they are often soaked in water for long periods of time and are subjected to heavy machinery use during land preparation and harvesting, which makes them more susceptible to soft soil development. The development of soft soils could lower rice yields as the heavy agricultural machines used during harvesting cannot harvest ripened crops in soft soil areas due to the low mechanical strength of the soft soil.

Conventional methods such as soil replacement techniques and the use of engineering machines offer the best chance for improving soft soils, but they are still far from satisfactory in the long-term as the soil still loses its stiffness post improvement. Furthermore, the cost required to mechanically improve soft soils is extremely high. In Malaysia, based an official report stated that almost 15 billion USD is 
being spent to mitigate soft soil issues. Therefore, a reliable, effective, and non-destructive and inexpensive method to overcome soft soil problems is being sought. The application of an organic amendment is considered an alternative approach to improve soil physico-chemical properties as it is effective and more economical. Many studies have found that organic amendments such as biochar (Vaughn et al., 2018), humic acid (Pramanik et al., 2019), compost (Safaei Khorram et al., 2019), and sewage sludge (Rodríguez-Berbel et al., 2020), can improve soil properties in the long term. The present study used an organic amendment that is made of a mixture of materials, including clinoptilolite, kieserite, humic acid, and rubber bark dust. The main components of this amendment are rubber bark dust at $53 \%$ and clinoptilolite at $24 \%$. All of the materials used in this product are readily available. This study used rubber bark dust as a primary component because it is enriched with $\mathrm{Mg}$ and $\mathrm{K}$ elements. Furthermore, rubber bark dust is wasted from agriculture and wood industry sectors thus it will be useful if it can be used for other benefits. At present, this specific organic amendment has been used to improve paddy field fertility and thereby increase rice production in Malaysia. The normal amount applied to one hectare is $250 \mathrm{~kg}$, after the first plowing during field preparation. Previous studies have shown that its application to the rice fields was free of contamination (Rendana et al., 2018). The cost of applying the specific organic amendment to one hectare of a paddy field is approximately USD 250. The performance of the specific organic amendment has been tested, and it has demonstrated outstanding results when used to enhance soil physico-chemical properties. Our previous study found that the specific organic amendment is capable of improving critical physico-chemical characteristics in paddy fields such as $\mathrm{pH}$, which increased from an initial $\mathrm{pH}$ value of 3.91 to 6.09, cation exchange capacity improved from 9.56 to $18.39 \mathrm{cmolc}$ $\mathrm{kg}^{-1}$, and total soil organic carbon content from 0.67 to $3.14 \%$ (Rendana et al., 2018, 2019).

Recent studies of soft soil improvement techniques are frequently associated with engineering approaches (Al-Bared et al., 2019; Al-Bared et al., 2018; Jafer et al., 2018; Lemos et al., 2020; Onyelowe et al., 2019; Wang et al., 2019; Zainuddin et al., 2019). Studies of the relationship between mineralogical, microstructure, and mechanical strength properties of soft soil in paddy fields are still lacking. Therefore, the objective of this study is to improve the mechanical strength of soft paddy soil using organic amendment. This improvement in mechanical strength is explained by the observed changes in soil mineralogical and microstructure composition. The change in mineralogical composition from clay type 1:1 kaolinite to a clay type 2:1 smectite promotes stronger structural bonds results in a more compact soil structure that may improve the stability of soil such that organic amendment treated soft soil areas can withstand the impact of heavy machinery use. Because in this study we only used one paddy cultivation area, thus for future research we suggest comparing it with other paddy areas which are degraded by soft soil issues. It will provide more information about the soft soil properties in the paddy field area and give us the best planning for mitigating the problem.
Outputs of the study can be suggested to give an alternative technique in improving soft paddy soil characteristics which it is more economical and efficient than other conventional techniques. Furthermore, the use of rubber bark dust-zeolite composite amendment also can help to increase rice production in the study area.

\section{MATERIAL AND METHODS}

\subsection{Experimental design and soil sampling}

This study was carried out at paddy field areas in Alor Pudak, Kedah, Malaysia (latitude $6^{\circ} 3^{\prime} 29.10^{\prime \prime} \mathrm{N}$ and longitude $100^{\circ} 28^{\prime} 16.30^{\prime \prime E}$ ). This area has experienced low rice yields due to soft soil problems. The study area has been divided into five treatments. The treatments were labeled according to the doses of organic amendment applied in the soil, i.e.: $0 \mathrm{~kg}$ (control plot or P0), $125 \mathrm{~kg}$ (P1), $250 \mathrm{~kg}$ (P2), $375 \mathrm{~kg}$ (P3), and $500 \mathrm{~kg}$ (P4). These treatments were replicated in five plots with a size of 0.20 ha for each plot. The plots were separated by small drains $( \pm 1 \mathrm{~m}$ ) to avoid transboundary movement of the applied materials. Each drain had a length of 1 meter where the water outlet from each plot is not connected to each other plots. Prior to conducting field trials, the organic amendment was prepared. The organic amendment, made from rubber bark dust (53\%), clinoptilolite (24\%) as the main component, and the remaining components such as humic acid (20\%) and kieserite (3\%). The basic properties of the amendment were analyzed in the laboratory (Table 1). The basic characteristics of soft soil samples were determined using standard methods in the laboratory before they were treated (Table 2). Prior to mixing organic amendment into the soil, water was added by irrigation system until the soil was damp but not overly to soaked. Due to the large doses of the organic amendment being applied, the organic amendment material was sown into the soil by a machine using a sweeping motion. After sowing, a plowing machine was used to obtain a homogenous wet soilorganic amendment mixture. After plowing, the plots were again put in a water basin until the soil was saturated. Finally, the plots were left to dry for 105 days and then mineralogical, microstructural, and mechanical strength properties were analyzed. Soil samples (0-15 cm depth) were compositely taken using Dutch Auger in each plot. Soil samples were brought to the laboratory for further soil analysis.

Table 1. Basic properties of the organic amendment from our measurement in the laboratory.

\begin{tabular}{llc}
\hline Parameter & Unit & Values \\
\hline $\mathrm{SiO}_{2}$ & $\%$ & 21.56 \\
$\mathrm{MgO}$ & $\%$ & 6.79 \\
$\mathrm{CaO}$ & $\%$ & 3.92 \\
$\mathrm{~K}_{2} \mathrm{O}$ & $\%$ & 1.95 \\
$\mathrm{Al}_{2} \mathrm{O}_{3}$ & $\%$ & 5.86 \\
$\mathrm{Fe}_{2} \mathrm{O}_{3}$ & $\%$ & 1.91 \\
$\mathrm{Na}_{2} \mathrm{O}$ & $\%$ & 1.05 \\
$\mathrm{SO}_{3}$ & $\%$ & 16.82 \\
$\mathrm{Organic}_{3}$ matter & $\mathrm{OM}(\%)$ & 41.69 \\
pH water (1:2.5) & & 8.05 \\
$\mathrm{Cation}$ exchange capacity & $\mathrm{CEC}\left(\mathrm{cmol}_{\mathrm{c}} \mathrm{kg}^{-1}\right)$ & 20.17 \\
Electrical conductivity & $\mathrm{EC}\left(\mathrm{mS} \mathrm{cm}^{-1}\right)$ & 3.50 \\
\hline
\end{tabular}


Table 2. Basic properties of soft soil sample from our measurement in the laboratory.

\begin{tabular}{|c|c|c|}
\hline Parameter & & Values \\
\hline \multirow[t]{11}{*}{ Chemical } & $\mathrm{SiO}_{2}$ & $59.4 \%$ \\
\hline & $\mathrm{Fe}_{2} \mathrm{O}_{3}$ & $4.25 \%$ \\
\hline & $\mathrm{Al}_{2} \mathrm{O}_{3}$ & $21.79 \%$ \\
\hline & $\mathrm{K}_{2} \mathrm{O}$ & $1.88 \%$ \\
\hline & $\mathrm{TiO}_{2}$ & $1.08 \%$ \\
\hline & $\mathrm{Na}_{2} \mathrm{O}$ & $0.11 \%$ \\
\hline & $\mathrm{CaO}$ & $0.22 \%$ \\
\hline & $\mathrm{MgO}$ & $0.82 \%$ \\
\hline & $\mathrm{P}_{2} \mathrm{O}_{5}$ & $0.17 \%$ \\
\hline & $\mathrm{pH}$ water (1:2.5) & 3.20 \\
\hline & CEC & $7.97 \mathrm{cmoc}_{\mathrm{c}} / \mathrm{kg}$ \\
\hline \multirow[t]{5}{*}{ Mineralogy } & Major & $\begin{array}{l}\text { Quartz } \\
\text { Kaolinite }\end{array}$ \\
\hline & Secondary & $\begin{array}{l}\text { Smectite } \\
\text { Illite }\end{array}$ \\
\hline & & Feldspar \\
\hline & & Goethite \\
\hline & & Muscovite \\
\hline \multirow[t]{12}{*}{ Physical } & Texture & Silty Clay \\
\hline & Sand & $10 \%$ \\
\hline & Silt & $49 \%$ \\
\hline & Clay & $41 \%$ \\
\hline & Organic matter & $2.16 \%$ \\
\hline & Soil moisture content & $48.02 \%$ by wt. \\
\hline & Bulk density & $0.93 \mathrm{~g} \mathrm{~cm}^{-3}$ \\
\hline & $\begin{array}{l}\text { Water-stable } \\
\text { aggregate }\end{array}$ & $16.08 \%$ \\
\hline & Soil cohesion & $10-20 \mathrm{kPa}$ \\
\hline & Soil color & $\begin{array}{c}2.5 Y 3 / 1 \text { very } \\
\text { dark }\end{array}$ \\
\hline & Soil order & Inceptisols \\
\hline & Soil great group & $\begin{array}{c}\text { Sulfic } \\
\text { Endoaquepts }\end{array}$ \\
\hline
\end{tabular}

\subsection{Soil mineralogical analysis}

The mineralogical composition of the soft soil samples was analyzed using the X-ray diffraction (XRD) analysis with the instrument of the Bruker/D8 Advance. For XRD analysis, the soil samples with $63 \mu \mathrm{m}$ size were weighed about $1 \mathrm{~g}$ and prepared on polished thin disks. These thin disks were then dehydrated and impregnated with resin under vacuum conditions according to Secchi et al. (2018). Lastly, the XRD result was processed using Bruker Software to generate quantitative data such as sample peak position, peak intensity, crystallization, and mineral content of the soil samples.

\subsection{Soil microstructural analysis}

The microstructure of the soft soil samples was analyzed using the scanning electron microscope (SEM) analysis with the instrument of the Zeiss SUPRA 55VP microscope. Approximately $1 \mathrm{~g}$ of the soil samples with a size of $63 \mu \mathrm{m}$ was prepared for SEM analysis according to Secchi et al. (2018). Then, the soil samples were coated with a thin layer of conductive material and read using the SEM microscope. In this study, we searched for images of flocculation or consolidation in the soil particles. The images were analyzed at several magnifications such as $5.00 \mathrm{KX}, 10.00 \mathrm{KX}$ and 30.00 $K X$. Then, the images that showed clearly the flocculation process was chosen for the soil microstructural analysis.

\subsection{Soil mechanical strength analysis}

The soil strength was measured by the Unconsolidated Undrained Triaxial Compression Test (UU-Test) method based on Secchi et al. (2018). Soil samples were collected from each plot using Shelby tubes. The Shelby tube was inserted into the soil profile to obtain a soil sample approximately $37 \mathrm{~mm}$ in diameter and $75 \mathrm{~mm}$ in height. After sampling, the Shelby tubes were fully covered with thick plastic and carried to the mechanical laboratory for analysis. After transferring the sample from the Shelby tube, about 1-5 g of the soil samples were taken to determine the moisture content and the remainder was used for the UU-Test. The UU-test results provided soil physical and mechanical properties such as soil moisture content (\% by wt.), bulk density, apparent cohesion, lateral pressure, deviator stress, and total normal stress values. The UU-test results were statistically analyzed by plotting the apparent cohesion, moisture content, and bulk density against the organic amendment addition. The classification of soil strength values for soft soil was obtained from Ahmad et al. (2021) as shown in Table 3.

\subsection{Statistical analysis}

Statistical analysis of means and variation was carried out using Tukey's test (HSD) in the IBM SPSS Statistics 21.

\section{RESULTS}

\subsection{Mineralogical properties of soft soil}

The X-ray diffraction (XRD) spectra of soft soil samples are shown in Figure 1. The XRD results reveal the presence of minerals such as quartz (Qz), kaolinite (Ka), smectite (Sm), calcite (Ca), goethite (Ge), muscovite (Mc), and feldspar (Fd) in the untreated plot or PO (Fig. 1a). However, in all the treated plots (P1, P2, P3, and P4), new minerals such as clinoptilolite $(\mathrm{Cl})$, dolomite (Do), kieserite $(\mathrm{Ki})$, and gibbsite (Gb) were observed (Fig. 1b-e). The soft soil samples consisted of clay minerals mainly of the kaolinite and smectite types with negligible illite. In the PO plot, the predominant mineral was present kaolinite (Fig 1a). It is observed at a diffraction angle of $5 \stackrel{2}{0} \theta$. After organic amendment application, the kaolinite intensity decreased from 2100 to 750 whereas the smectite mineral intensity value increased from 1200 to 1300 (Fig. 1b-e). This result demonstrates that there were clear changes in the kaolinite and smectite content of the treated plots. The smectite peak at diffraction

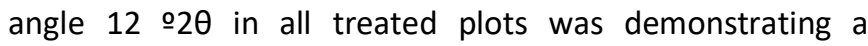
significant increase in the intensity value compared to the untreated plot.

Table 3 Classification of cohesion values for soil.

\begin{tabular}{lc}
\hline \multicolumn{1}{c}{ Soil condition } & Cohesion, $\mathrm{kPa}$ \\
\hline Very soft & $<24$ \\
Soft & $24-<48$ \\
Medium & $48-<96$ \\
Stiff & $96-<192$ \\
Very stiff & $192-<383$ \\
\hline
\end{tabular}

Source: Terzaghi et al. (1996). 
However, there were no significant differences in the smectite XRD spectra between the treated plots. The other new minerals detected in the treated plots were distributed in particular diffraction patterns in all of the analyzed samples. For instance, the clinoptilolite peak was observed at

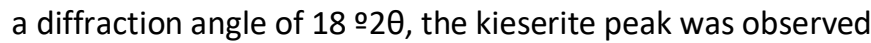

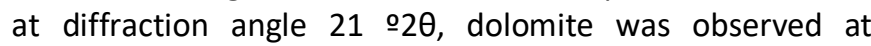
diffraction angle $34 \stackrel{2 \theta}{ } \theta$ and gibbsite was observed at diffraction angle 52 으 (Fig. $1 \mathrm{~b}-\mathrm{e}$ ).

\subsection{Microstructural properties of soft soil}

Scanning Electron Microscope (SEM) images captured evidence of soil particle flocculation in the treated plots (Fig. $2 b-e)$. The amount of flocculation increased proportionally with the amount of organic amendment added. The treated soil structures were found to be tighter than those in the untreated soil. This was evidenced by the reduced number of pores in soil structure following organic amendment applications, furthermore, the structure of the treated soil appeared more compact compared to that of untreated soil. In contrast, the SEM images of the untreated plot displayed no evidence of soil particle flocculation (Fig. 2a). The soil structures in the untreated plot tended to be less compact and have many large voids of approximately $250-500 \mathrm{~nm}$ in between soil aggregates (Fig. 2a). SEM image of kaolinite minerals in the untreated plot displayed a hexagonal shape, they stacked and piled into larger aggregates to form booklets or vermiform aggregates. The smectites minerals detected in the treated plots appeared as honeycomb structures in SEM images.

\subsection{Soil mechanical strength properties}

The mechanical strength of treated and untreated plots was determined using apparent cohesion $(\mathrm{Cu})$ values from the unconsolidated undrained triaxial compression test (UUTest). The results show apparent cohesion values that vary from 15 to $58 \mathrm{kPa}$ (Fig. 3).
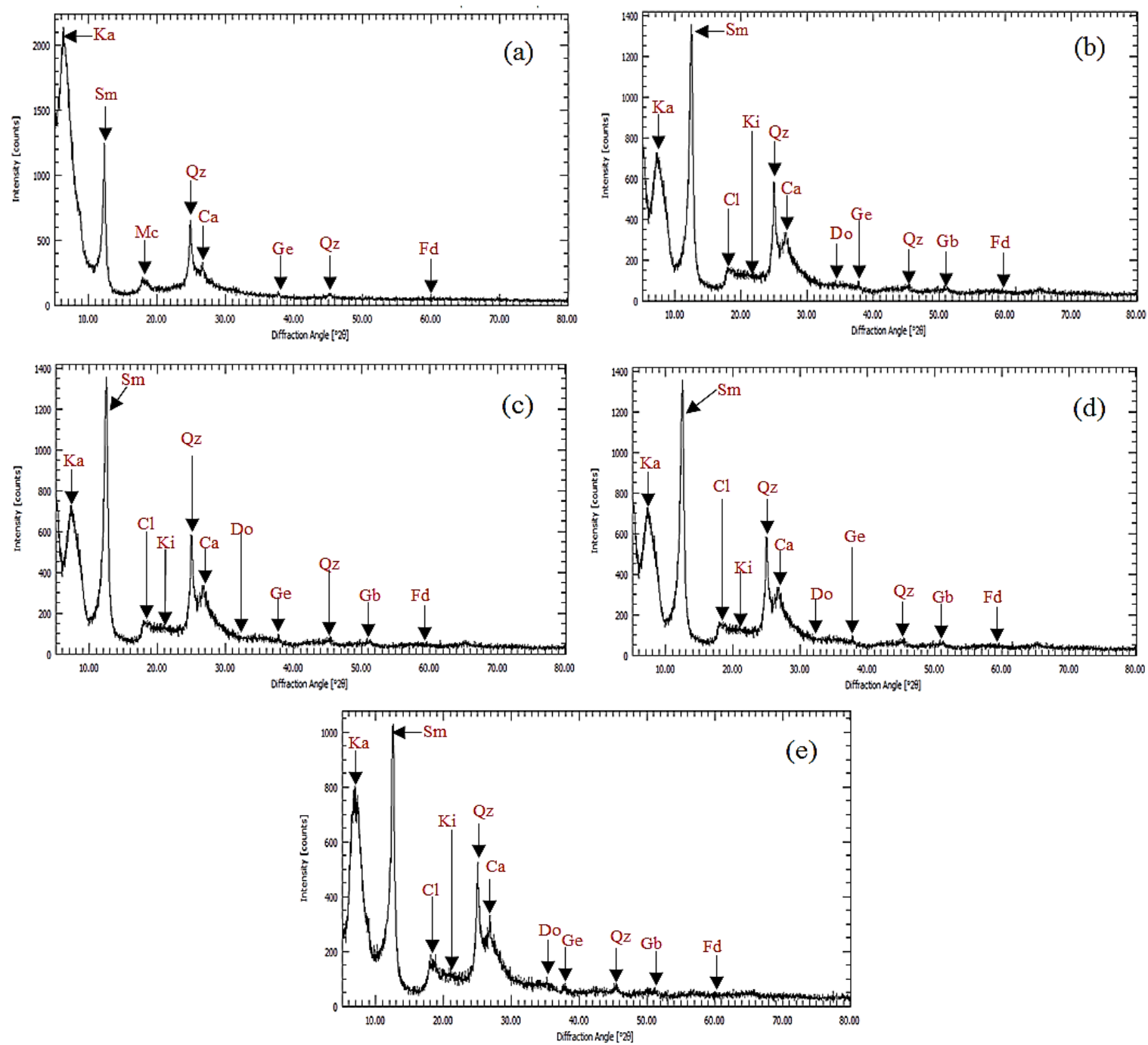

\section{Major Phases:}

Qz - Quartz, Ka - Kaolinite, Sm - Smectite, Cl - Clinoptilolite, Ca - Calcite, Do - Dolomite, Ge - Geoethite, Gb - Gibbsite, Ki - Kieserite, Mc - Muscovite, Fd - Feldspar

Figure 1. X-ray diffraction spectra of mineral in soft soil samples: (a) $P 0=0 \mathrm{~kg}$; (b) $P 1=125 \mathrm{~kg}$; (c) $P 2=250 \mathrm{~kg}$; (d) P3= $375 \mathrm{~kg}$; and (e) P4= $500 \mathrm{~kg}$ 

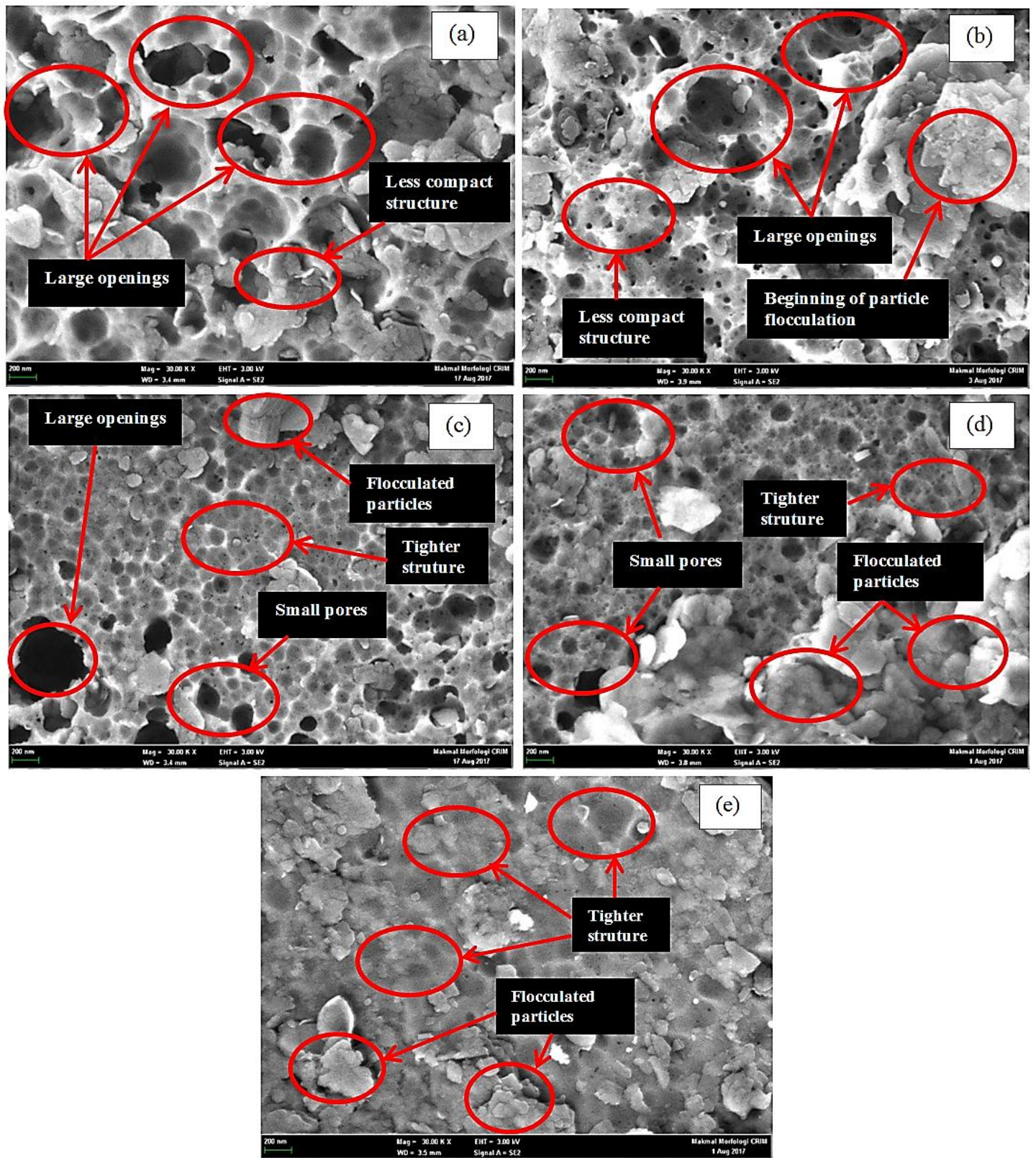

Figure 2. Scanning Electron Microscope (SEM) images of soft soil samples: (a) P0= 0 kg; (b) P1= 125 kg; (c) P2= 250 kg; (d) P3= $375 \mathrm{~kg}$; and (e) P4= $500 \mathrm{~kg}$

The highest apparent cohesion value was found with $500 \mathrm{~kg}$ of the organic amendment (P4), while the lowest value was found in the untreated plot (PO). The results of this study indicate that apparent cohesion values in all treated plots were significantly higher than that of the untreated plot $(p<0.05)$. The apparent cohesion values increased as the amount of organic amendment added increased. An apparent cohesion value of $48 \mathrm{kPa}$ is the threshold value indicating that soils have adequate mechanical performance. The UU-test result revealed that the threshold value can be achieved when $250 \mathrm{~kg}$ of the organic amendment (P2) is added. The apparent cohesion value in the $\mathrm{P} 2$ was approximately $50 \mathrm{kPa}$, which is slightly higher than the threshold value (Fig. 3). The variation in moisture content is presented in percent by weight and bulk density values in the untreated and treated plots obtained from the UU-Test are presented in Figure 4. The moisture content ranged from 18 to $43 \%$. The moisture content decreased as the amount of organic amendment increased. The moisture content in the treated plots was significantly lower than those in the untreated plot $(p<0.05)$. On the other hand, the bulk density values in the treated plots were significantly higher than that in the untreated plot $(p<0.05)$. The bulk density values vary from 1.07 to $1.26 \mathrm{~g} \mathrm{~cm}^{-}$ ${ }^{3}$. The highest bulk density value is found after treatment with $500 \mathrm{~kg}$ of the organic amendment (P4). Overall, the bulk density values increased with increasing amounts of the organic amendment.

\section{DISCUSSION}

In this study, the organic amendment was employed to improve the properties of soft soil such as mineralogical content, microstructure, and mechanical strength. To date, studies on soft soil improvement were limited to engineering 
approaches. The results of the current study offered new insight into how this soft soil improvement method could be carried out. This study showed that organic amendment could be used to enhance the mechanical strength of soft soil. In this study, the changes in mineralogical, microstructure, and mechanical properties of the soil after the application of the amendment were taken as important indicators demonstrating the improvement of soft soil. The resulting mineral composition and presence of stabilized microstructures increased the mechanical performance of the soft soil. Previous studies have shown that organic amendments could be used to mitigate issues associated with sodic soil (Choudhary et al., 2011), acid soil stress (Ai et al., 2015), heavy metal-contaminated soil (Zhou et al., 2018), and alkaline soil (Arif et al., 2017).

As presented in Figure 1, the XRD spectra showed the variance in minerals in soft soil samples subjected to the application of the organic amendment. The high spectrum of kaolinite in the untreated plot was driven by the abundance of this mineral in the soil (Fig. 1a). In this study, the soft soil samples had low $\mathrm{pH}$ values (<3.5, Table 2) and were categorized as acid sulfate soil (Tanaka et al., 2021). These higher kaolinite contents in these soft soil samples were due to the common presence of the kaolinite mineral phase in acid sulfate soil (Shamshuddin et al., 2014). Following organic amendment application, the kaolinite spectra decreased, while the smectite spectra significantly increased. The formation of smectite was driven by the increase in Si content resulting from the addition of organic amendment. The organic amendment had high Si content (Table 1). This indicated that there was a decrease in crystallinity in all treated plots compared to the untreated plots, which was consistent with a transition from kaolinite to increased smectite. There was a significant difference in smectite content between the samples with increasing amounts of the organic amendment. In general, smectite had stronger consolidation properties than kaolinite and therefore tended to create stable soil aggregates (Fissore et al., 2016). The results of the XRD analysis implicated new minerals, such as clinoptilolite and kieserite detected in all treated plots. These minerals were very prominent in soil amendment as both could enhance soil parameters such as nutrient availability (Latifah et al., 2017), water availability (Rashidzadeh et al., 2015), and heavy metal alleviation (Mühlbachová et al., 2005). Based on the results of this study, clinoptilolite was also capable of improving the mechanical strength of the soil. Furthermore, the existence of gibbsite in all treated plots was affected by soil $\mathrm{pH}$. As the soil $\mathrm{pH}$ was increased above 5.0, following organic amendment treatment, Al began to precipitate and formed a gibbsite (Azman et al., 2014).

As shown in Figure 2, SEM images of the untreated plot showed a largely open microstructure, with kaolinite assembled in a dispersed arrangement, leaving many voids approximately $250-500 \mathrm{~nm}$ in dimension (Fig. 2a). The SEM images of all treated plots indicated that there were changes in the microstructure of the soil matrix, evidenced by the presence of compact structures (Fig. 2b-e). Another result from this study is the observation of soil particle flocculation, which began after $250 \mathrm{~kg}$ organic amendment addition.

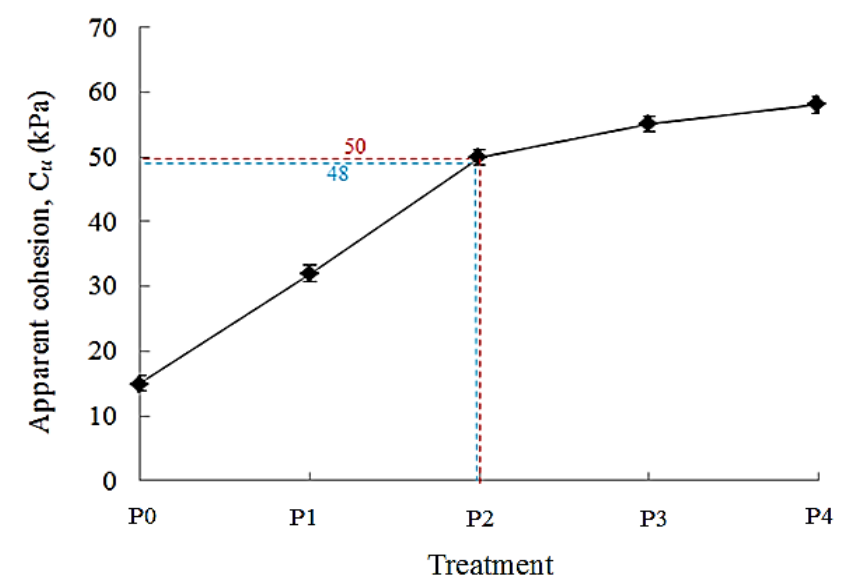

Figure 3. Variation in apparent cohesion $\left(C_{u}\right)$ values against organic amendment addition. Red line indicates $\mathrm{C}_{u}$ value at $250 \mathrm{~kg}$ of organic amendment (P2) and blue line indicates threshold value. Error bars represent standard errors (Note: $\mathrm{P} 0=0 \mathrm{~kg} ; \mathrm{P} 1=125$ $\mathrm{kg}$; $\mathrm{P} 2=250 \mathrm{~kg} ; \mathrm{P} 3=375 \mathrm{~kg}$; and $\mathrm{P} 4=500 \mathrm{~kg}$ )

As the amounts of organic amendment increased to 375 $\mathrm{kg}$ (P3) and $500 \mathrm{~kg}$ (P4), the flocculated nature of the microstructure became more prominent. The increase in the degree of reticulation, which resembles reticular-like structures was influenced by the increase in clinoptilolite content. Clinoptilolite had unique characteristics that help to improve the physico-chemical properties of soil such as ion exchange capacity, high absorption, and easily molded features (Nur Aainaa et al., 2018). Clinoptilolite-driven flocculation in soil particles occurred via a cation exchange process, where $\mathrm{Ca}^{2+}$ replaced $\mathrm{Na}^{+}$and $\mathrm{K}^{+}$ions in the soil. The apparent cohesion $(\mathrm{Cu})$ value of all treated plots was measured (Fig. 3) to determine a fixing point a threshold value at which the soil starts to reach a sufficient mechanical performance. This threshold value was taken from the work of Terzaghi et al. (1996), which was estimated using the value of unconfined compressive strength. The obtained $\mathrm{Cu}$ values of the untreated and treated plots at different doses of the organic amendment are presented in Figure 3. The result showed a significant increase in Cu between $0 \mathrm{~kg}$ (PO) and 250 $\mathrm{kg}$ of the organic amendment (P2). Beyond that, the $\mathrm{Cu}$ value continued to rise slightly. This might be due to the previously reached threshold value ( $48 \mathrm{kPa}$ ) at $250 \mathrm{~kg}$ of the organic amendment. Obtaining the fixing point at $250 \mathrm{~kg}$ of added organic amendment supports the results of the XRD and SEM analysis, where tighter soil structures are observed with 250 $\mathrm{kg}$ (P2) and $500 \mathrm{~kg}$ of the organic amendment (P4).

Increased $\mathrm{Cu}$ values in all treated plots can be explained by the addition of $\mathrm{Mg}^{2+}$ and $\mathrm{Ca}^{2+}$ cations from the organic amendment. These cations have high soil stabilization potential. Bond formation is influenced by soil $\mathrm{pH}$ and the cation exchange process. Previous studies found that a higher soil $\mathrm{pH}$ will change positive charges to negative, leading to changes in soil structure (Delgado \& Gómez, 2016; Farahani et al., 2018). The increased number of negative charges on the soil surface promotes active flocculation and thus, the formation of soil structure. This is consistent with the results of the current study, where flocculated structures were found following organic amendment application. 


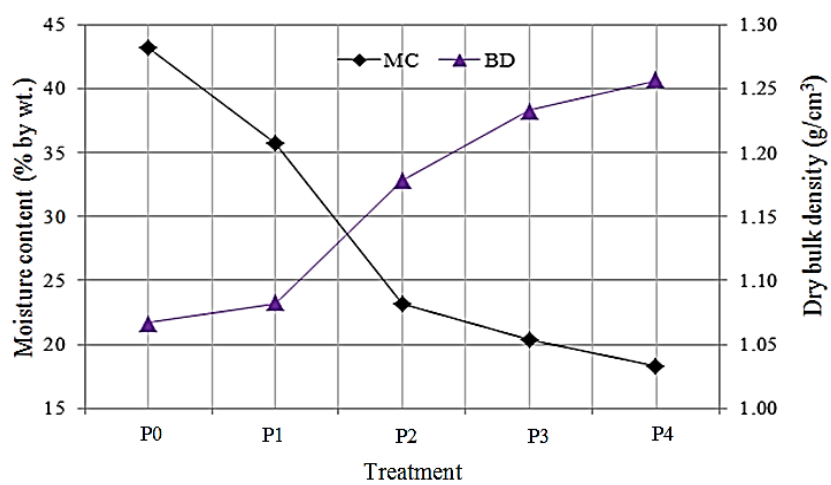

Figure 4. Variation in moisture content, \% by wt. (MC) and dry bulk density, $\mathrm{g} \mathrm{cm}^{-3}(\mathrm{BD})$ values against organic amendment addition (Note: $\mathrm{PO}=0 \mathrm{~kg} ; \mathrm{P} 1=125 \mathrm{~kg}$; $\mathrm{P} 2=250 \mathrm{~kg} ; \mathrm{P} 3=375 \mathrm{~kg}$; and $\mathrm{P} 4=500 \mathrm{~kg}$ )

Figure 4 shows the dynamic compaction curve of treated plots based on moisture content and bulk density. The treated plots showed higher bulk density values than the untreated plot, while their moisture content was lower. Therefore, the soil becomes drier and denser due to mixing with the organic amendment. The organic amendment contains zeolite materials (i.e., clinoptilolite) that mixed well with the soil to form a compact structure as shown in the SEM images. This compact structure produced a high total of micropores in the soil as the bulk density increased. These micropore spaces in compact soil hold less water than that of the untreated plot.

Soil moisture content is an essential parameter when studying soft soil because higher water content can contribute to lower soil strength. The P4 plot showed the lowest moisture content that indicated the highest addition of the organic amendment contributed to increasing the soil strength. A study by Khasib and Daud (2020) obtained moisture content values that showed a reduced pattern from 24.7 to $17.5 \%$, and dry density rose from $1.37 \mathrm{~g} \mathrm{~cm}^{-3}$ to $1.73 \mathrm{~g}$ $\mathrm{cm}^{-3}$ after soft soils were treated using an amendment material. If we compared our result, we found that the moisture content showed a higher decrease (43 to 18\%) after applying the organic amendment. In contrast, the dry density showed a lower increase from 1.07 to $1.26 \mathrm{~g} \mathrm{~cm}^{-3}$. Nasir et al. (2019) also revealed that there was no effect of tractor pressure on soil strength, but it could differ from agricultural practice, soil moisture content, climate, and irrigation system. Based on the results of this study, both moisture content $(r=$ -0.94, $p<0.01)$ and bulk density $(r=0.95, p<0.01)$ had significant impacts on soil strength. This finding is consistent with our previous study (Rendana et al., 2018), which found a similarly significant relationship between soil moisture and soil strength with $r=-0.61, p<0.05$. Overall, the moisture content in soft soil samples was found to decrease with organic amendment addition.

Furthermore, clay content and type also affected soil strength due to their role in cohesion. The clay content could significantly govern their cohesion. A significant decrease in moisture content has been observed in all treated plots due to the addition of organic amendment which promoted the formation of micropore space, thus reducing adsorbed water and forming stable soil structure. The reduced moisture content did not affect the available water content for paddy plants. In nature, soft soils were characterized by low bearing capacity and high-water content. The process explained above might represent a mechanism for the stabilization of soft soil. The organic amendment materials tended to coat soil particles, resulting in a denser wrapping during compaction. Additionally, finer organic amendment materials would fill voids between soil particles to form a denser soil matrix.

\section{CONCLUSION}

The organic amendment method was used to improve the soft soil strength. The soft soil strength values were found an increase with changes in mineralogical composition from kaolinite to smectite minerals after applying the organic amendment. The microstructure of treated plots was more compact than that of the untreated plot, and the soil strength of treated plots was significantly increased to the optimum level for resisting agricultural machine pressure. In conclusion, the organic amendment provides the best opportunity for improving the properties of soft paddy soil. For future research, soft soil improvement using the organic amendment can be applied to mitigate other paddy field areas with the same problem.

\section{Declaration of Competing Interest}

The authors declare no competing financial or personal interests that may appear and influence the work reported in this paper.

\section{References}

Ahmad, M. T., Khadzir, M. K., \& Omar, M. F. Z. (2020). Performance of a Triangular Rubber Tracked Tractor in Paddy Fields. Advances in Agricultural and Food Research Journal, 1(2). https://doi.org/10.36877/aafrj.a0000132

Ahmad, M. T., Zaman, O. M. F., Fauzi, M. I. M., Khusairy, K. M., Sharu, E. H., Hashim, A. M., Azlan, O., Saifulizan, M. N., Bunyamin, A. K., \& Mansor, N. (2021). Effect of Mole drain and Tracked Agricultural Prime Movers on Soft Soil Paddy Areas. Advances in Agricultural and Food Research Journal, 2(2), 1-8. https://doi.org/10.36877/aafrj.a0000228

Ai, C., Liang, G., Sun, J., He, P., Tang, S., Yang, S., Zhou, W., \& Wang, X. (2015). The alleviation of acid soil stress in rice by inorganic or organic ameliorants is associated with changes in soil enzyme activity and microbial community composition. Biology and Fertility of Soils, 51(4), 465-477. https://doi.org/10.1007/s00374-0150994-3

Al-Bared, M. A., Harahap, I. S., Marto, A., Abad, S. V. A. N. K., Mustaffa, Z., \& Ali, M. O. (2019). Mechanical behaviour of waste powdered tiles and Portland cement treated soft clay. Geomechanics and Engineering, 19(1), 37-47. https://doi.org/10.12989/gae.2019.19.1.037

Al-Bared, M. A. M., Harahap, I. S. H., \& Marto, A. (2018). Sustainable strength improvement of soft clay stabilized with two sizes of recycled additive. 
GEOMATE Journal, 15(51), 39-46. https://geomatejournal.com/geomate/article/view/1 004

Arif, M., Ilyas, M., Riaz, M., Ali, K., Shah, K., Ul Haq, I., \& Fahad, S. (2017). Biochar improves phosphorus use efficiency of organic-inorganic fertilizers, maize-wheat productivity and soil quality in a low fertility alkaline soil. Field Crops Research, 214, 25-37. https://doi.org/10.1016/j.fcr.2017.08.018

Azman, E. A., Shamshuddin, J., Ishak, C. F., \& Ismail, R. (2014). Increasing rice production using different lime sources on an acid sulphate soil in Merbok, Malaysia. Pertanika Journal of Tropical Agricultural Science, 37(2), 223247.

http://www.pertanika.upm.edu.my/pjtas/browse/reg ular-issue?article=JTAS-0494-2013

Choudhary, O. P., Ghuman, B. S., Bijay, S., Thuy, N., \& Buresh, R. J. (2011). Effects of long-term use of sodic water irrigation, amendments and crop residues on soil properties and crop yields in rice-wheat cropping system in a calcareous soil. Field Crops Research, 121(3), 363-372. https://doi.org/10.1016/j.fcr.2011.01.004

Delgado, A., \& Gómez, J. A. (2016). The Soil. Physical, Chemical and Biological Properties. In F. J. Villalobos \& E. Fereres (Eds.), Principles of Agronomy for Sustainable Agriculture (pp. 15-26). Springer International Publishing. https://doi.org/10.1007/978-3-319-46116-8_2

Farahani, E., Emami, H., \& Keller, T. (2018). Impact of monovalent cations on soil structure. Part II. Results of two Swiss soils. International Agrophysics, 32(1), 6980. https://doi.org/10.1515/intag-2016-0092

Fauzi, M., Padzil, M. N., Chan, C. S., Herman, E., Taufik, M., Khusairy, M., Fitri, M., Shah, M. S., Aufa, M., \& Hanif, M. (2018). Effects of five seasons in two years paddy planting programme on soil bearing capacity. Journal of Built Environment, Technology and Engineering, 4, 252-257. https://jbete.org/wpcontent/uploads/2018/05/JBETE4_90-92.pdf

Fissore, C., Jurgensen, M. F., Pickens, J., Miller, C., PageDumroese, D., \& Giardina, C. P. (2016). Role of soil texture, clay mineralogy, location, and temperature in coarse wood decomposition-a mesocosm experiment. Ecosphere, 7(11), e01605. https://doi.org/10.1002/ecs2.1605

Jafer, H. M., Atherton, W., Sadique, M., Ruddock, F., \& Loffill, E. (2018). Development of a new ternary blended cementitious binder produced from waste materials for use in soft soil stabilisation. Journal of Cleaner Production, 172, 516-528. https://doi.org/10.1016/j.jclepro.2017.10.233

Khasib, I. A., \& Daud, N. N. N. (2020). Physical and Mechanical Study of Palm Oil Fuel Ash (POFA) based Geopolymer as a Stabilizer for Soft Soil. Pertanika J. Sci. Technol, 28(S2), 149-160. https://doi.org/10.47836/pjst.28.s2.12

Latifah, O., Ahmed, O. H., \& Majid, N. M. A. (2017). Enhancing nitrogen availability from urea using clinoptilolite zeolite. Geoderma, 306, 152-159. https://doi.org/10.1016/j.geoderma.2017.07.012

Lemos, J., Santos-Ferreira, A., \& da Silva, P. F. (2020). Geotechnical modelling to appraise the Tavira (Portugal) new fishing harbor's soft soils compressibility. In P. D. Long \& N. T. Dung (Eds.), Geotechnics for Sustainable Infrastructure Development (pp. 1353-1358). Springer Singapore. https://www.springerprofessional.de/en/geotechnica I-modelling-to-appraise-the-tavira-portugal-newfishi/17447796

Mühlbachová, G., Simon, T., \& Pechová, M. (2005). The availability of $\mathrm{Cd}, \mathrm{Pb}$ and $\mathrm{Zn}$ and their relationships with soil $\mathrm{pH}$ and microbial biomass in soils amended by natural clinoptilolite. Plant Soil Environ, 51(1), 26-33. https://doi.org/10.17221/3552-PSE

Nasir, R. M., Su, A., Yahya, A., Nawi, N. M., \& Wagiman, N. (2019). Soil Compaction Effects of Rubber-Wheel Tractors and Half-Track Tractors in Rice Cultivation. Konvensyen Kebangsaan Kejuruteraan Pertanian dan Makanan,

Nur Aainaa, H., Haruna Ahmed, O., \& Ab Majid, N. M. (2018). Effects of clinoptilolite zeolite on phosphorus dynamics and yield of Zea Mays L. cultivated on an acid soil. PLOS ONE, 13(9), e0204401. https://doi.org/10.1371/journal.pone.0204401

Onyelowe, K., Bui Van, D., Igboayaka, C., Orji, F., \& Ugwuanyi, H. (2019). Rheology of mechanical properties of soft soil and stabilization protocols in the developing countries-Nigeria. Materials Science for Energy Technologies, 2(1), 8-14. https://doi.org/10.1016/j.mset.2018.10.001

Pramanik, P., Safique, S., \& Jahan, A. (2019). Humic substrates extracted by recycling factory tea waste improved soil properties and tea productivity: an innovative approach. International Journal of Environmental Science and Technology, 16(7), 3761-3770. https://doi.org/10.1007/s13762-018-1791-y

Rashidzadeh, A., Olad, A., \& Reyhanitabar, A. (2015). Hydrogel/clinoptilolite nanocomposite-coated fertilizer: swelling, water-retention and slow-release fertilizer properties. Polymer Bulletin, 72(10), 26672684. https://doi.org/10.1007/s00289-015-1428-y

Rendana, M., Idris, W. M. R., Rahim, S. A., Rahman, Z. A., Lihan, T., \& Jamil, H. (2018). Reclamation of acid sulphate soils in paddy cultivation area with organic amendments. AIMS Agriculture and Food, 3(3), 358371. https://doi.org/10.3934/agrfood.2018.3.358

Rendana, M., Idris, W. M. R., Rahim, S. A., Rahman, Z. A., Lihan, T., \& Jamil, H. (2019). Effects of Organic Amendment on Soil Organic Carbon in Treated Soft Clay in Paddy Cultivation Area. Sains Malaysiana, 48(1), 61-68. https://doi.org/10.17576/jsm-20194801-07

Rodríguez-Berbel, N., Ortega, R., Lucas-Borja, M. E., SoléBenet, A., \& Miralles, I. (2020). Long-term effects of two organic amendments on bacterial communities of calcareous mediterranean soils degraded by mining. 
Journal of Environmental Management, 271, 110920. https://doi.org/10.1016/j.jenvman.2020.110920

Safaei Khorram, M., Zhang, G., Fatemi, A., Kiefer, R., Maddah, K., Baqar, M., Zakaria, M. P., \& Li, G. (2019). Impact of biochar and compost amendment on soil quality, growth and yield of a replanted apple orchard in a 4year field study. Journal of the Science of Food and Agriculture, 99(4), 1862-1869. https://doi.org/https://doi.org/10.1002/jsfa.9380

Secchi, M., Zanatta, M., Borovin, E., Bortolotti, M., Kumar, A., Giarola, M., Sanson, A., Orberger, B., Daldosso, N., Gialanella, S., Mariotto, G., Montagna, M., \& Lutterotti, L. (2018). Mineralogical investigations using XRD, XRF, and Raman spectroscopy in a combined approach. Journal of Raman Spectroscopy, 49(6), 1023-1030.

https://doi.org/https://doi.org/10.1002/jrs.5386

Shamshuddin, J., Azura, A. E., Shazana, M., Fauziah, C., Panhwar, Q., \& Naher, U. (2014). Properties and management of acid sulfate soils in Southeast Asia for sustainable cultivation of rice, oil palm, and cocoa. Advances in Agronomy, 124, 91-142. https://doi.org/10.1016/B978-0-12-800138-7.00003-6

Tanaka, S., Saito, H., Kajiwara, N., Paing, T. N., Mohd Yusoff, K. H., Abe, S. S., Nakao, A., \& Yanai, J. (2021). Longterm changes in paddy soil fertility in Peninsular Malaysia during 50 years after the Green Revolution with special reference to their physiographic environments. Soil Science and Plant Nutrition, 67(1), 80-88.

https://doi.org/10.1080/00380768.2020.1840264
Taufik, A. M., Khusairy, K. M., \& Fauzi, M. I. M. (2015). Performance of a Quad-Steel Tracked Tractor on Paddy Field Malaysian Soil Science Conference. Malaysian Soil Science Society (MSSS),

Terzaghi, K., Peck, R. B., \& Mesri, G. (1996). Soil mechanics in engineering practice (3rd ed.). John Wiley \& Sons.

Vaughn, S. F., Dan Dinelli, F., Jackson, M. A., Vaughan, M. M., \& Peterson, S. C. (2018). Biochar-organic amendment mixtures added to simulated golf greens under reduced chemical fertilization increase creeping bentgrass growth. Industrial Crops and Products, 111, 667-672.

https://doi.org/10.1016/j.indcrop.2017.11.036

Wang, J.-H., Desai, C. S., \& Zhang, L. (2019). Soft Soil and Related Geotechnical Engineering Practice. International Journal of Geomechanics, 19(11), 02019001. https://doi.org/10.1061/(ASCE)GM.19435622.0001494

Zainuddin, N., Mohd Yunus, N. Z., Al-Bared, M. A. M., Marto, A., Harahap, I. S. H., \& Rashid, A. S. A. (2019). Measuring the engineering properties of marine clay treated with disposed granite waste. Measurement, 131,

50-60. https://doi.org/10.1016/j.measurement.2018.08.053 Zhou, H., Meng, H., Zhao, L., Shen, Y., Hou, Y., Cheng, H., \& Song, L. (2018). Effect of biochar and humic acid on the copper, lead, and cadmium passivation during composting. Bioresource Technology, 258, 279-286. https://doi.org/10.1016/j.biortech.2018.02.086 